\title{
EFFECTS OF NICKEL AND ITS COMBINATION WITH OTHER HEAVY METALS (Cd, Pb, Zn) ON COMMON CARP (Cyprinus carpio Linnaeus, 1785)
}

\author{
K. Todorova', I. Velcheva ${ }^{2}$, V. Yancheva ${ }^{2}$, S. Stoyanova ${ }^{2}$, S. Petrova $^{2 *}$, E. Georgieva ${ }^{2}$ \\ ${ }^{1}$ Lyuben Karavelov Branch, University of Plovdiv, Kardzhali, Bulgaria \\ ${ }^{2}$ Faculty of Biology, University of Plovdiv, Plovdiv, Bulgaria
}

\begin{abstract}
We aimed to study ex-situ the effects of acute toxicity test with $\mathrm{Ni}^{2+}, \mathrm{Ni}+\mathrm{Cd}, \mathrm{Ni}+\mathrm{Pb}$ and $\mathrm{Ni}+\mathrm{Zn}$ on behavior, survival and oxygen consumption of common carp, Cyprinus carpio L. Behavioral effects were more pronounced in fish exposed to $0.2 \mathrm{mg} / 1^{1} \mathrm{Ni}^{2+}, 0.3 \mathrm{mg} / 1 \mathrm{Ni}^{2+}$ and $0.45 \mathrm{mg} / 1 \mathrm{Ni}^{2+}$. Common stress reactions, such as anxiety, jumps and quick movements, and also accelerated movements of the fish gill covers were observed. Fish behavior from the lower $\mathrm{Ni}^{2+}$ concentrations $\left(0.05\right.$ and $\left.0.1 \mathrm{mg} / 1 \mathrm{Ni}^{2+}\right)$ and from the test combinations of $\mathrm{Ni}+\mathrm{Cd}, \mathrm{Ni}+\mathrm{Pb}$ and $\mathrm{Ni}+\mathrm{Zn}$ was quite different. In general, during the first hours of the experiment the fish were anxious, but after 48 hours they started to be lethargic, which was expressed in their slow movements. Fish survival was $90 \%$ under intoxication with $0.2 \mathrm{mg} / 1 \mathrm{Ni}^{2+}$ and combination of $\mathrm{Ni}+\mathrm{Pb}$. In the rest of the tested heavy metal concentrations it was $100 \%$. Data on the respiration intensity rate and oxygen consumption of fish exposed to $0.2 \mathrm{mg} / \mathrm{l} \mathrm{Ni}^{2+}, 0.3 \mathrm{mg} / \mathrm{l} \mathrm{Ni}^{2+}, \mathrm{Ni}+\mathrm{Pb}$ and $\mathrm{Ni}+\mathrm{Cd}$ were lower in comparison with the control group. This result indicated that the $\mathrm{Ni}^{2+}$ ions impacted the fish respiratory system. Depending on their toxic effect the descending row of the studied heavy metals could be presented as follows: $\mathrm{Ni}^{2+}>\mathrm{Ni}+\mathrm{Pb}>\mathrm{Ni}+\mathrm{Cd}>\mathrm{Ni}+\mathrm{Zn}$. Overall, such experiments could be successfully applied in environmental monitoring and risk assessment programs for metalcontaminated aquatic ecosystems and toxic effects on fish.
\end{abstract}

Key words: Heavy metals, Acute test, Survival, Behavior, Oxygen consumption, Fish, Cyprinus carpi

\section{INTRODUCTION}

Heavy metal pollution has begun to grow at an alarming rate [1] because heavy metals cannot degrade, and they are continuously deposited and incorporated into water, sediments, and aquatic organisms. Pollution of natural waters by metals released by different anthropogenic activities such as increased population, urbanisation, domestic, industrial, and agricultural processes is an environmental problem of global significance which have been further aggravated $[2,3,4]$.

In the Annual Report of the Basin Directorate - Plovdiv, 2009, Section 2 from the management plan for the river basin in the East Region 2010-2015, Volume 2 - River Arda, heavy metals are pointed as the most significant contributors to water pollution. Common contaminants are copper $(\mathrm{Cu})$, manganese $(\mathrm{Mn})$, zinc $(\mathrm{Zn})$, and other

\footnotetext{
* Correspondence to: Slaveya Petrova, ${ }^{2}$ Faculty of Biology, University of Plovdiv, 24 Tzar Assen Str., 4000 Plovdiv, Bulgaria, Tel: +359 32261 519, Email: new_line@mail.bg
}

priority substances according to Directive 2013/39/EU [5] of the European Parliament and of the Council regarding priority substances in the field of water policy cadmium $(\mathrm{Cd})$, lead $(\mathrm{Pb})$ and nickel $(\mathrm{Ni})$. Contamination with these toxic elements has been found throughout the whole catchment area of River Arda until the boderline with Greece. Their distribution also suggests accumulation in the food chain and possible environmental consequences that this freshwater ecosystem could face are still unknown.

Among aquatic organisms, fish are generally considered to be the most relevant organism for pollution monitoring in aquatic ecosystems [6]. They are also relatively situated at the top of the aquatic food chain; therefore, fish normally can accumulate heavy metals from food, water and sediments [7, 8]. Additionally, they are low in cholesterol and contain beneficial poly-unsaturated fatty acids [9] thus the contaminant levels in fish present a considerable concern for human health [10-13]. 
Elevated concentrations of metals can be toxic to aquatic life because they are able to induce oxidative stress by accelerating the generation of highly reactive oxygen species (ROS), including superoxide radical $\left(\mathrm{O}_{2}{ }^{-}\right)$, hydrogen peroxide $\left(\mathrm{H}_{2} \mathrm{O}_{2}\right)$, hydroxyl radicals $\left(\mathrm{OH}^{*}\right)$, and singlet oxygen species $\left({ }^{1} \mathrm{O}_{2}\right)$. If not detoxified, these ROS can oxidize proteins, lipids and nucleic acids, often leading to enzymatic and morphological changes, altered physiological processes and even cell death [14].

There is a large amount of literature regarding heavy metals such as $\mathrm{Cd}, \mathrm{Cu}, \mathrm{Hg}, \mathrm{Pb}$ and $\mathrm{Zn}$, and their toxic effects on biota [15-18]. However, there is insufficient data on $\mathrm{Ni}^{2+}$ toxicity and in particular, on its combination with other heavy metals on the degree of expression of oxidative stress. Hence, the aim of the present study is to examine ex situ the impact of: (i) increasing $\mathrm{Ni}^{2+}$ concentrations; (ii) and combined effect of $\mathrm{Ni}+\mathrm{Cd}, \mathrm{Ni}+\mathrm{Pb}$ and $\mathrm{Ni}+\mathrm{Zn}$, on the survival, behavior, respiratory processes and oxygen consumption in common carp (Cyprinus carpio L.) under acute metal exposure.

\section{MATERIAL AND METHODS Experimental set up}

The experiment was performed at the laboratory of Lyuben Karavelov Branch, University of Plovdiv. Duration of the toxicity tests was $96 \mathrm{~h}$. Nine aquaria of 1001 volume were used for each $\mathrm{Ni}^{2+}$ concentration and its combination with other heavy metals -5 with $\mathrm{Ni}^{2+}$ in different concentrations (shown below), 3 for $\mathrm{Ni}+\mathrm{Cd}, \mathrm{Ni}+\mathrm{Pb}$ and $\mathrm{Ni}+\mathrm{Zn}$ and 1 for control with no heavy metals added in the water. Water temperature was maintained constant by a heater monitor (Sharc-H-229). Water was continuously aerated by pumps (Atec-AR-850 and Hailea-HT-BT 2000). Water properties such as: temperature, $\mathrm{pH}$, oxygen saturation, conductivity and water hardness was measured with a combined fieldmeter (WTW) (Table 1).

Nickel $\left(\mathrm{Ni}^{2+}\right)$ was used as $\mathrm{Ni}\left(\mathrm{NO}_{3}\right)_{2} \cdot 6 \mathrm{H}_{2} \mathrm{O}$; cadmium $\left(\mathrm{Cd}^{2+}\right)$ as $\mathrm{Cd}\left(\mathrm{NO}_{3}\right)_{2} \cdot 4 \mathrm{H}_{2} \mathrm{O}$; lead $\left(\mathrm{Pb}^{2+}\right)$ as $\mathrm{Pb}\left(\mathrm{NO}_{3}\right)_{2}$ and zinc $\left(\mathrm{Zn}^{2+}\right)$ as $\mathrm{Zn}\left(\mathrm{NO}_{3}\right)_{2} \cdot 6 \mathrm{H}_{2} \mathrm{O}$, respectively (Merck). The increasing concentrations of $\mathrm{Ni}^{2+}$ were 0.05 $\mathrm{mg} / \mathrm{l}, 0.1 \mathrm{mg} / \mathrm{l}, 0.2 \mathrm{mg} / \mathrm{l}, 0.3 \mathrm{mg} / \mathrm{l}$ and 0.45 $\mathrm{mg} / \mathrm{l}$.

Test concentrations of the combined heavy metals were determined after preliminary testing and single exposure to different concentrations of $\mathrm{Cd}, \mathrm{Pb}$ and $\mathrm{Zn}$. In the present experiment the lowest observed effect concentration (LOEC) for each metal: $\mathrm{Cd}-$ $0.01 \mathrm{mg} / \mathrm{l}, \mathrm{Pb}-0.05 \mathrm{mg} / \mathrm{l}$ and $\mathrm{Zn}-3.0 \mathrm{mg} / \mathrm{l}$, was chosen. Endpoint was the death of fish.

Table 1. Physico-chemical properties of the water in every tank used it the experiment

\begin{tabular}{cccccccccc}
\hline $\begin{array}{c}\text { Metal } \\
\begin{array}{c}\text { concentration } \\
(\mathrm{mg} / \mathrm{l})\end{array}\end{array}$ & $\begin{array}{c}0.05 \\
\mathrm{Ni}^{2+}\end{array}$ & $\begin{array}{c}0.1 \\
\mathrm{Ni}^{2+}\end{array}$ & $\begin{array}{c}0.2 \\
\mathrm{Ni}^{2+}\end{array}$ & $\begin{array}{c}0.3 \\
\mathrm{Ni}^{2+}\end{array}$ & $\begin{array}{c}0.45 \\
\mathrm{Ni}^{2+}\end{array}$ & $\mathrm{Ni}+\mathrm{Cd}$ & $\mathrm{Ni}+\mathrm{Pb}$ & $\mathrm{Ni}+\mathrm{Zn}$ & control \\
\hline $\mathrm{pH}$ & $7.5 \pm 0.22$ & $7.2 \pm 0.07$ & $7.2 \pm 0.08$ & $7.1 \pm 0.06$ & $7.2 \pm 0.06$ & $7.4 \pm 0.07$ & $7.6 \pm 0.17$ & $7.3 \pm 0.09$ & $7.5 \pm 0.21$ \\
$\mathrm{t}^{\circ} \mathrm{C}$ & $22.4 \pm 0.4$ & $23.0 \pm 0.1$ & $21.0 \pm 0.9$ & $22.2 \pm 0.7$ & $22.9 \pm 0.3$ & $21.9 \pm 0.1$ & $22.1 \pm 0.1$ & $21.9 \pm 0.1$ & $22.2 \pm 0.8$ \\
$\mathrm{O}_{2}, \mathrm{mg} / \mathrm{l}$ & $7.2 \pm 0.15$ & $7.5 \pm 0.11$ & $7.3 \pm 0.18$ & $7.3 \pm 0.08$ & $7.5 \pm 0.14$ & $7.3 \pm 0.03$ & $7.3 \pm 0.05$ & $7.2 \pm 0.2$ & $8.2 \pm 0.05$ \\
$\begin{array}{c}\text { Conductivity } \\
\mu \mathrm{S} / \mathrm{cm}\end{array}$ & $119.1 \pm 11$ & $129.6 \pm 16$ & $133.2 \pm 23$ & $127.1 \pm 17$ & $154.7 \pm 25$ & $101.1 \pm 6$ & $142.3 \pm 11$ & $108.4 \pm 12$ & $112.6 \pm 11$ \\
\hline
\end{tabular}

\section{Experimental animals}

Common carp (Cyprinus carpio L.) is a cyprinid species used in aquaculture and recreational fishing. It is also one of the most preferred protein source through Europe and particularly, in Bulgaria. Furthermore, common carp is a very resilient to water contamination and that is why, it is very often recommended for the purposes of ecotoxicological research [19-21]. Common carps of equal size and age $(12 \pm 2 \mathrm{~cm}$ length and $9.5 \pm 25 \mathrm{~g}$ weight) were used. They were purchased from the certified fish farm 'Venikol' Ltd. (Kardzhali, Bulgaria). Fish had no external lesions and injuries. After acclimatisation in de-chlorinated (by evaporation) water for 7 days, 10 fish were placed in each experimental aquarium. We monitored the fish behavior - mobility, location in the tank and opening and closing of their gill covers twice daily. Every 24 hours during the experiment the number of survived fish in each aquarium was recorded and and the dead ones (if any) were removed.

Respiration intensity was examined after the 96-hour exposure to the test concentrations ended. Two marked fish of each experimental tanks were chosen, measured, weighed and placed in a new aquarium, filled with dechlorinated water. The aquarium was isolated from the air through stretch film and the fish were left for 1 hour [22]. Oxygen 
content in the water was measured at the beginning $(\mathrm{Q})$ and at the end $\left(\mathrm{Q}_{1}\right)$ of the experiment with an oximeter (pHenomenalOX-4000H-VWR). Respiration intensity was determined by the following formula:

$$
\mathrm{I}=\mathrm{Q}_{2} / \mathrm{G} \text {, }
$$

where $\mathrm{I}$ is the intensity of respiration (oxygen quantity in $\mathrm{mg} \mathrm{O}_{2}$ on $1 \mathrm{~g}$ fish weight for 1 hour); $\mathrm{G}$ - fish weight in $\mathrm{g}$; $\mathrm{Q}_{2}-$ oxygen consumption for $1 \mathrm{~h}$ (oxygen quantity in the begging minus oxygen quantity at the end, as follows $\mathrm{Q}_{2}=\mathrm{Q}-\mathrm{Q}_{1}$ ).

Fish resistance to oxygen deficiency was examined directly following our previous experiment [23] according to the method by Tsekov [22]. We also monitored the fish behaviour.

The present study was performed in accordance with national and international guidelines of the European Parliament and the Council on the protection of animals used for scientific purposes (Directive 2010/63/EU) [24].

\section{Statistical analysis}

All data were statistically processed by calculating the Pearson correlation coefficient $(\mathrm{P}<0.05)$ with software packet Statistika 7.0 StatSoft Inc. [25].

\section{RESULTS AND DISCUSSION Behaviour}

Immediately after the $\mathrm{Ni}^{2+}$ was added in the first five aquaria, we observed sharp spasmodic contractions of the muscle of the fish mouth and frequent gill cover movements. Some fish were anxious, jumping quickly towards the water surface. These effects were most severe in the fish exposed to higher $\mathrm{Ni}^{2+}$ concentrations. After the first 24 hours, the fish from the lower $\mathrm{Ni}^{2+}$ concentrations $(0.2$, 0.3 and $0.45 \mathrm{mg} / \mathrm{l}$ ) were apatic, they formed groups close to the bottom of the aquaria with slow and lethargic movements, excreting mucus. During the first hours of the experiment the fish were anxious, but after 48 hours they started to be lethargic, which was expressed in slow movements close to the bottom of the aquaria. On the bodies of some of the fish from the tested $\mathrm{Ni}^{2+}$ concentrations we found a thick layer of mucus, most likely secreted because of the metal-contaminated water. Menne et al. [26] explain this fact with the strong irritant capacity that soluble nickel salts have towards the fish skin. Similar results were also reported by El-Saieed and Mekawy [27].

Behavior of the fish from the combined metal exposures was less pronounced compared to the high concentrations of single $\mathrm{Ni}^{2+}$ exposures. The most anxious were the carps of the combination $\mathrm{Ni}+\mathrm{Pb}$. This behavior lasted up to 24 hours after the experiment started. After 48 hours until 96-th hour, it was replaced by lethargy, expressed in slow movements, mainly oriented to the bottom of the tank. Fish of the last two combinations - $\mathrm{Ni}+\mathrm{Cd}$ and $\mathrm{Ni}+\mathrm{Zn}$ made slight movements towards the bottom of the aquarium in the last 72 hours of exposure. We consider that such behavior is a possible way to reduce or delay the flow of metal-contaminated water over the gills.

\section{Survival}

Fish survival was $90 \%$ under intoxication with $0.2 \mathrm{mg} / \mathrm{l} \mathrm{Ni}^{2+}$ and its combination with $\mathrm{Pb}$. In the rest of the tested heavy metals concentrations it was $100 \%$.

\section{Respiration Intensity Rate}

In our research the data on the respiration intensity rate of the fish exposed to single $\mathrm{Ni}^{2+}$ were higher in comparison with the control group (Table 2). In addition, the data showed lower absorbed oxygen results compared to the control group. This result indicated that the $\mathrm{Ni}^{2+}$ ions impacted the fish respiratory system. We consider that such increase in the respiration intensity rate could be a compensatory mechanism, most likely connected with altered respiratory functions of the gills and oxygen transport. On the other hand, the results Javid et al. [28] found a positive correlation between the $\mathrm{Ni}^{2+}$ concentrations and quantities absorbed oxygen. On the opposite, our results showed no such trend. In this sense, Abou- Hadeed et al. [29] provided data on morphological and functional changes in the gills after $\mathrm{Ni}^{2+}$ exposure.

Data for absorbed oxygen and respiration intensity of the fish exposed to $\mathrm{Ni}^{2+}$ and its combination with $\mathrm{Cd}, \mathrm{Pb}$ and $\mathrm{Zn}$ for the fish exposed to $\mathrm{Ni}+\mathrm{Cd}$ and $\mathrm{Ni}+\mathrm{Pb}$ showed a lower respiration intensity rate and absorbed oxygen levels compared to the control. In addition, those for fish exposed to $\mathrm{Ni}+\mathrm{Zn}$ showed similar results to the control, showing that this metal combination is the least stressful.

\section{Resistance to oxygen deficiency}

The exposed fish dropped in the following order: $\mathrm{Ni}+\mathrm{Pb}$ at $0.07 \mathrm{mg} / \mathrm{l} \mathrm{O}_{2} ; \mathrm{Ni}+\mathrm{Zn}$ at 0.05 $\mathrm{mg} / \mathrm{l} \mathrm{O}_{2} ; \mathrm{Ni}+\mathrm{Pb}$ at $0.04 \mathrm{mg} / \mathrm{l} \mathrm{O}_{2} ; 0.45 \mathrm{Ni}^{2+}$ at $0.03 \mathrm{mg} / \mathrm{l} \mathrm{O} \mathrm{O}_{2} ; 0.2 \mathrm{Ni}^{2+}$ at 0.02 and $0.00 \mathrm{mg} / \mathrm{l}$ $\mathrm{O}_{2}$. The individuals from the other $\mathrm{Ni}^{2+}$ concentrations and its combinations with $\mathrm{Cd}$, $\mathrm{Pb}$ and $\mathrm{Zn}$ dropped over the next 40 minutes at concentrations of $0.00 \mathrm{mg} / \mathrm{l} \mathrm{O}$. After aeration for 15 minutes $100 \%$ from the control fish 
TODOROVA K. et al.

recovered and $50 \%$ from the fish exposed to $0.05 \mathrm{Ni}^{2+}, 0.1 \mathrm{Ni}^{2+}$ and $\mathrm{Ni}+\mathrm{Cd}$, as well as $50 \%$ from the fish exposed to $0.3 \mathrm{Ni}^{2+}$ and $\mathrm{Ni}+\mathrm{Zn}$.

Table 2. Data on absorbed oxygen and respiration intensity levels of common carp under metal exposure

\begin{tabular}{cccccccccc}
\hline $\begin{array}{c}\text { Metal } \\
\text { concentration } \\
(\mathrm{mg} / \mathrm{l})\end{array}$ & 0.05 & 0.1 & 0.2 & 0.3 & 0.45 \\
$\mathrm{Ni}^{2+}$ & $\mathrm{Ni}^{2+}$ & $\mathrm{Ni}^{2+}$ & $\begin{array}{c}\mathrm{Ni}^{2+} \\
\mathrm{Ni}^{2+}\end{array}$ & $\mathrm{Ni}+\mathrm{Cd}$ & $\mathrm{Ni}+\mathrm{Pb}$ & $\mathrm{Ni}+\mathrm{Zn}$ & control \\
\hline $\begin{array}{c}\text { Absorbed } \\
\text { oxygen } \\
\text { (mg O2) }\end{array}$ & 1.55 & 2.3 & 1.55 & 1.6 & 2.2 & 1.81 & 1.84 & 2.02 & 2.2 \\
$\begin{array}{c}\text { Respiration } \\
\text { intensity } \\
(\mathrm{mg} / \mathrm{g})\end{array}$ & 0.01 & 0.0099 & 0.01 & 0.012 & 0.009 & 0.007 & 0.008 & 0.009 & 0.009 \\
\hline
\end{tabular}

The order of lethal outcome for fish in this study showed that despite of the high survival rate for 96-hour exposure of all tested concentrations, the $\mathrm{Ni}^{2+}$ caused damage to the respiratory system. This damage was more serious in one of the combinations and higher $\mathrm{Ni}^{2+}$ concentrations. In general, the results for resistance to oxygen deficiency confirmed those for respiration intensity. According to Ololade and Oginni [30], the lethal outcome after $\mathrm{Ni}^{2+}$ exposure is due to stress, which weakens the fish body's resistance or due to the cumulative impact of $\mathrm{Ni}^{2+}$ toxicity.

\section{CONCLUSIONS}

Depending on their toxic effects on the fish the descending row of the studied heavy metals could be presented as follows: $\mathrm{Ni}>\mathrm{Ni}+\mathrm{Pb}>$ $\mathrm{Ni}+\mathrm{Cd}>\mathrm{Ni}+\mathrm{Zn}$. In general, we can conclude that $\mathrm{Ni}^{2+}$ toxicity is moderate to fish (and other aquatic organisms) in comparison with other heavy metals. This opinion is in agreement with Nebeker et al. [31] and Khangarot and Ray [32]. Phenology and abnormal behavior of carp such as constant umping and gulping of air, increased opercular acivities, sharp mouth opening, sudden surface to bottom movements, restlessness and lethargic movements are sensitive indicators of sub-lethal toxic effects. They can be used for early diagnosis of lesions. Overall, such fish experiments are relatively fast, inexpensive and reliable, thus they could be successfully included in environmental monitoring and risk assessment programs for metal-contaminated aquatic ecosystems.

\section{REFERENCES}

1. Abdel-Baki, A. S., Dkhil, M. A. and AlQuraishy, S., Bioaccumulation of some heavy metals in tilapia fish relevant to their concentration in water and sediment of Wadi Hanifah, Saudi Arabia. Afr J Biotechnol, 10(13): 2541-2547, 2011.
2. Gupta, A., Rai, D. K., Pandey, R. S. and Sharma, B., Analysis of some heavy metals in the riverine water, sediments and fish from Ganges at Allahabad. Environ. Monit Assess, 157(1-4): 449-58, 2009.

3. Loro, V. L., Jorge, M. B., Da Silva, K. R. and Wood, C. M., Oxidative stress parameters and antioxidant response to sublethal waterborne zinc in a euryhaline teleost Fundulus heteroclitus: protective effects of salinity. Aquat Toxicol, 110: 187-193, 2012.

4. Mastan, S. A., Heavy metals concentration in various tissues of two freshwater fishes, Labeo rohita and Channa striatus. Afr $J$ Environ Sci Technol, 8(2): 166-170, 2014.

5. Directive 2013/39/EU of the European parliament and of the council of 12 August 2013 amending Directives 2000/60/EC and 2008/105/EC as regards priority substances in the field of water policy. Official Journal of the European Union.

6. Van der Oost, R., Beyer, J. and Vermeulen, N. P. E., Fish bioaccumulation and biomarkers in environmental risk assessment: A review. EnvironToxicol Pharmacol, 13:57149, 2003.

7. Taweel, A., Shuhaimi-Othman, M. and Ahmad, A. K., Heavy metal concentration in different organs of tilapia fish (Oreochromis niloticus) from selected areas of Bangi, Selangor, Malaysia. Afr J Biotechnol, 10(55):11562-11566, 2011.

8. Zhao, S., Feng, C., Quan, W., Chen, X., Niu, J. and Shen, Z., Role of living environments in the accumulation characteristics of heavy metals in fishes and crabs in the Yangtze River Estuary, China. Mar Pollut Bull, 64(6):1163-1171, 2012.

9. Ersoy B. and Celik M., The essential and toxic elements in tissues of six commercial demersal fish from Eastern Mediterranean Sea. Food Chem Toxicol, 48: 13771382, 2010. 
10. Copat, C., Bella, F., Castaing, M., Fallico, R., Sciacca, S. and Ferrante, M., Heavy metals concentrations in fish from Sicily (Mediterranean Sea) and evaluation of possible health risks to consumers. Bull Environ Contam Toxicol, 88(1): 78-83, 2012.

11. Squadrone, S., Prearo, M., Brizio, P., Gavinelli, S., Pellegrino, M., Scanzio, T., Guarise, S., Benedetto A. and Abete M. C., Heavy metals distribution in muscle, liver, kidney and gill of European catfish (Silurus glanis) from Italian Rivers. Chemosphere, 90(2): 358-365, 2013.

12. Akoto, O., Bismark Eshun, F., Darko, G. and Adei, E., Concentrations and Health Risk Assessments of Heavy Metals in Fish from the Fosu Lagoon. Int J Environ Res, 8(2): 403-410, 2014.

13. Ahmed, Q. and Bat, L., Heavy metal levels in Euthynnus affinis (Cantor 1849) Kawakawa fish marketed at Karachi Fish Harbour, Pakistan and potential risk to human health. Black Sea/Mediter Environ,21(1):35-44, 2015

14. Lushchak V. I., Environmentally induced oxidative stress in aquatic animals. Aquat Toxicol, 101: 13-30, 2011.

15. Carrasco, L., Barata, C., García-Berthou, E., Tobias, A., Bayona, J. M. and Díez S., Patterns of mercury and methylmercury bioaccumulation in fish species downstream of a long-term mercury-contaminated site in the lower Ebro River (NE Spain). Chemosphere, 84(11): 1642-1649, 2011.

16. Hogstrand, C. Zinc. In: Wood CM, Farrell AP, Brauner CA (eds.), Homeostasis and Toxicology of Essential Metals - Fish Physiology, vol. 31A. Elsevier, San Diego, pp. 135-200, 2012.

17. Frías-Espericueta, M. G., Cardenas-Nava, N. G., Márquez-Farías, J. F., Osuna-López, J. I., Muy-Rangel, M. D., Rubio-Carrasco, W. and Voltolina D., Cadmium, copper, lead and zinc concentrations in female and embryonic Pacific sharpnose shark (Rhizoprionodon longurio). Tissues Bull Environ Contamin Toxicol, 93(5): 532-535, 2014.

18.Qu, R., Feng, M., Wang, X., Qin, L., Wang, C., Wang, Z. and Wang, L., Metal accumulation and oxidative stress biomarkers in liver of freshwater fish Carassius auratus following in vivo exposure to waterborne zinc under different $\mathrm{pH}$ values. Aquat Toxicol, 150: 9-16, 2014.

19. Snyder, E. M., Snyder, S. A., Kelly, K. L., Gross, T. S., Villeneuve, D.L., Fitzgerald, S. D. Villalobos, S. A., and Giesy, J. P., Reproductive responses of common carp (Cyprinus carpio) exposed in cages to influent of the Las Vegas Wash in Lake Mead, Nevada, from late winter to early spring. Environ Sci Technol, 38: 6385-6395, 2004.
20. Reynders, H., Bervoets, L., Gelders, M., De Coen, W. M. and Blust R., Accumulation and effects of metals in caged carp and resident roach along a metal pollution gradient in Flanders, Belgium. Sci Total Environ, 391: 82-95, 2008.

21. Mustafa, S. A., Karieb, S. S., Davies, S. J. and Jha, A. N., Assessment of oxidative damage to DNA, transcriptional expression of key genes, lipid peroxidation and histopathological changes in carp Cyprinus carpio L. following exposure to chronic hypoxic and subsequent recovery in normoxic conditions. Mutagenesis,30(1): 107-116, 2015

22. Tsekov, A., Studies on the Transferrin Polymorphism of Carp and Its Resistance to Oxygen Deficiency. Genet Selection, 22(6): 516-517, 1989.

23. Velcheva, I., Georgieva, E., Todorova, K. and Petrova, S., Biological systems - intoxication with heavy metals study on the survival and oxygen consumption of carp after 96-hour intoxication with heavy metals. Oxidat Commun 36(4): 1127-1134, 2013.

24. Directive 2010/63/EU of the European Parliament and of the Council of 22 September 2010 on the protection of animals used for scientific purposes. Official Journal of the European Union.

25.StatSoft Inc. 2004. STATISTICA (Data Analysis Software System), Vers. 7. Computer Software, htpp//www.statsoft.com

26. Menne,T., Borgan O. and Green, A. Nickel allergy and hand dermatitis in astratified sample of the Danish female population. Acta Dermatovenereol, 62 (1): 35-41, 1982.

27.El-Saieed, M. E. and Mekawy, M. M., Nickel Toxicity in Oreochromis niloticus fish. J Egypt Soc Toxicol, 24:47-54. 2001.

28. Javid, A., Javed, M. and Abdullah, S., Nickel bioaccumulation in the bodies of Catla catla, Labeo rohita and Cirrhina mrigala during 96hr LC50 Exposures. Int J Agric Biol, 9(1): 139-142, 2007.

29. Abou-Hadeed, A. H., Ibrahim, K. M., ElSharkawy, N. I., Saleh Sakr, F. M. and Abd El-Hamed, S. A., Experimental Studies on Nickel Toxicity in Nile Tilapia Health. $8^{\text {th }}$ international symposium on tilapia in aquaculture, 2008.

30. Ololade, I. A. and Oginni, O., Toxic stress and hematological effects of nickel on African catfish, Clarias gariepinus, fingerlings. J Environ Chem Ecotoxicol 2(2): 014-019, 2010.

31. Nebeker, A.V., Savonen, C., Stevens, D.G. Sensitivity of rainbow trout early life stages to nickel chloride. Environ Toxicol Chem, 4:233-239, 1985.

32. Khangarot, B.S. and Ray, P.K., Correlation between heavy metal acute toxicity values in Daphnia magna and fish. B Environ Contam Toxi, 38: 722-726, 1990. 
TODOROVA K. et al. 